\section{Flowers to leave the SRC}

Sir BRIAN Flowers, chairman of the Science Research Council, will succeed Lord Penney as Rector of Imperial College, University of London, on October 1, 1973. The announcement, made at the end of last week, comes only three months after Sir Brian agreed to continue in his present position for a further three years after his term of office expires in September of this year.

Sir Brian has made no secret of the fact that he hoped eventually to return to academic life, but last week's announcement comes as a surprise, particularly after Sir Brian's strong affirmation in February that he was going to stay on "to steer the SRC and the research council system generally through this difficult and confused period".

A spokesman for the Science $\mathrm{Re}$ search Council said this week, in Sir Brian's absence abroad, that Sir Brian wished to emphasize that his acceptance of the position at Imperial College did not signify a change of mind because no approaches about the rectorship had been made to him when he accepted the offer of a further three years at the helm of the SRC.

The extra year will, however, enable Sir Brian to initiate any changes within the council that prove to be needed in the light of the government's white paper on the future of government research and development, which is due to be published later this month. Discussions in which Sir Brian is expected to play a major part are about to start between the government and the research councils on the government's proposals.

Although Sir Brian's departure from

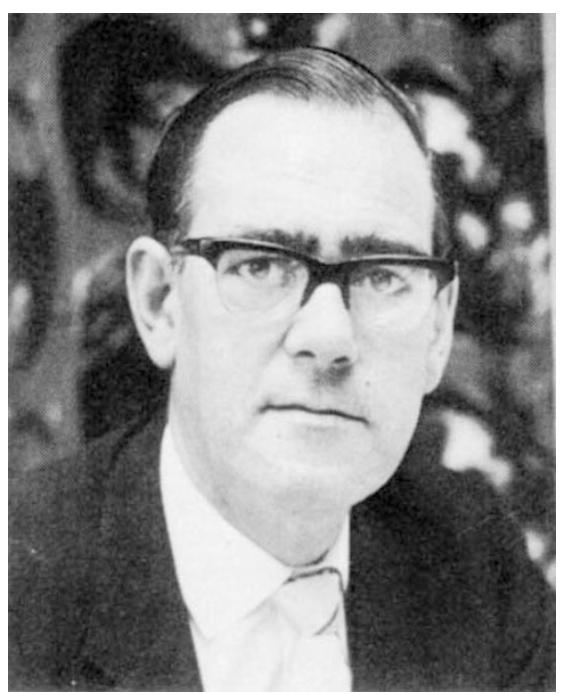

Sir Brian Flowers, Chairman of the Science Research Council. the SRC will be regretted by the scientific community, which sees Sir Brian as a champion of its cause for retaining the independence of the research councils, there is little doubt that the Department of Education and Science will heave a sigh of relief now that the date of his departure has been announced. It is an open secret that the DES and Sir Brian have not always been in complete accord.

The scene for Sir Brian's move was, in fact, set earlier this year when it was announced that he had resigned the Langworthy chair of physics at the University of Manchester, from which he had taken unpaid leave of absence in 1967 to be chairman of the SRC. This left him open to any other offers from the academic world that might come along.

\section{MEDICAL RESEARCH}

\section{Embryonic Protection}

THE adoption of a code of practice for the use of foetuses in medical research, and the creation of a central body to advise on ethical matters, are the chief recommendations contained in the report of a government advisory group published last week (The Use of Fetuses and Fetal Material for Research, HMSO, £0.185).

The advisory group, convened by the Department of Health and Social Security under the chairmanship of Sir John Peel, the Queen's gynaecologist, was established in May 1970 following accusations that abortion clinics were selling foetuses to medical researchers. The accusation came from Mr Norman St John-Stevas, MP, who was told by an anonymous "medical worker" in a London hospital that foetuses were "being kept alive for up to 40 weeks" for experimental purposes. This accusation proved to be unfounded and indeed to be scientifically impossible given the current state of knowledge, but one clinic had been selling foetuses for research purposes, The advisory group was set up within days of the accusations being made and clinics were warned that if they sold foetuses in future their licences would be revoked. Nonetheless the subject has remained an uneasy one and the advisory group's proposed code, if it is adopted, may well help allay public fears.

The chief points in the suggested code of practice are that because of advances in medical science the present legal definition of a viable foetus (one
Lord Penney, who will be 64 in September 1973, has decided to retire although there was no compulsion for him to do so. He has been rector since 1967 and before then he was chairman of the United Kingdom Atomic Energy Authority. Sir Brian has a similar background to Lord Penney, having spent the war years working on the Anglo-Canadian atomic energy project at Montreal and Chalk River and the post-war years involved in theoretical nuclear physics work at the UKAEA establishment at Harwell. In 1958 he took up a position as professor of theoretical physics at Manchester from which he came to the SRC.

Sir Brian's move to a university position in London is in the tradition set by his predecessor, Sir Harry Melville, who, after seeing the SRC through its teething troubles from 1965 to 1967 , left to be principal of Queen Mary College.

that can live as a self-sustaining whole, independently of its mother) should be changed, so that a foetus is considered viable at 20 weeks instead of at 28 as at present; that a foetus which is viable after separation from its mother should not be treated in any way which is not consistent with promoting its chances of survival ; and that nothing should be done to a foetus during pregnancy to ascertain what harm it might suffer (for example by the mother taking drugs), even if the mother intends to have an abortion later.

The advisory group, however, defends the use of foetuses and foetal material for research, both when the foetus is born dead and when it is born before it is viable, provided certain conditions are observed. Pre-viable foetuses should be used for research only when they weigh less than $300 \mathrm{~g}$ (a foetus of 20 weeks will weigh between 400 and $500 \mathrm{~g}$ ) and research on dead foetuses should not be restricted provided the relevant laws are observed.

Any suggestion of payment for foetuses, other than necessary costs, is strongly condemned by the advisory group. Research involving pre-viable foetuses should be carried out only in departments directly related to hospitals. Ethical committees should be set up in every institution where such work is undertaken, the committees to be guided by the suggested code of conduct. The group also recommends that a part-time central advisory body should be established with members from the Medical Research Council, the Royal College of Obstetricians and Gynaecologists, the General Medical Council and the British Paediatric Association. 